\title{
展 望 (2)
}

\section{医薬品の神経系に現われる副作用}

(I) 抗結核用について

梅 根 掊 一*

\section{I. はじめに}

昨今，わが国において，広い意味での医療原性 疾患が増加している，特に医楽品については，医 師も患者も必要以上に薬効を信頼し，薬品を濫用 する傾问がある．また一方では，現在有効とされ ている多くの薬品は, 副作用の強いことも周知の ところである.

医薬品による一般的な副作用の発生要因につい てみると，（I）薬理学的に起因する障害について は，（a）薬物の過量投与による.（b）投与方法に よる.（c）楽物の吸収, 排泄との関係. (d) 代謝 速度，代謝過程に酵素が関与するなどがある.

（II）患者の誤飲.（III）医療による過量投与（薬漬 けの問題). (IV) 個体差などを挙げ得る.

さて, 医薬品の中で, 神経系の副作用をもたら す代表的なものを挙げると，抗結核剤の多くは神 経に親和性をもつ特徵がある. そして, 神経毒と して中枢神経または末梢神経系の障害を惹起す る。また, 苘精神薬の多くは, 化学構造を異にす る楽物であるにもかかわらず，その薬理学的性質 や臨休効果の点で共通性が多いと同時に，副作用 として錐体外路系の症状や自律神経障害を起すと いつた欠点を持つている。その他，副腎皮質ホル モンによる精神障害. 最近注目されている整腸剤 キノホルムと SMON 病との関係など, 医薬品に よる神経系の副作用は枚挙すれば果しない。
今回，著者は第 1 編として抗結核剤による精神 神経系に及ぼす影響について述へ，第 2 編で向精 神薬, 一般医薬品による神経系の副作用を記した w.

\section{II. 抗結核剂}

多くの抗結核剤は神経毒であるため，神経系に 種々の副作用を呈することは周知のところであ る.すなわち，聴覚神経を選択的に障害するも の，末梢神経を障害し Neuropathy を惹起するも の，脳の中枢に作用して 精神障害を起すものなど である。

\section{1) 聴覚障害}

Streptomycin (SM), Kanamycin (KM), Viomycin (VM), その他, Neomycin (NM), Polymyxin (PL) などの抗生剂は神経障害を起すが, 特にアミノグリコシード系抗生剂である SNI, $\mathrm{KM}$ ，は第VIII脳神経障害を選択的に侵す代表的な ものである.PL は平衡失調, 視力障害, 四肢の しびれ感など中枢および末梢神経の障害をきたす とされている、SM 製剤で硫酸 SM は主に前庭 機能障害を, Dihydro-SM は聴神経により強く作 用し，高音聴力障害をもたらすとされている. $\mathrm{SM}$-難聴は $8,000 \mathrm{c} / \mathrm{s}$ から次第に $4,000 \mathrm{c} / \mathrm{s}$ 以下まで 侵され，2,000c/s 以下になると日常会話にも支障 がある. 原因は, 大量, 長期使用にさいし発現し 易い。しかし，数日，十数日で発症することがあ るので, 初期でも安心できない.また腎機能障害 
と聴力障害に执ても関連は深く， $\mathrm{SM} ， \mathrm{KM}$ の 血中濃度が高くなることに起因している。そのた め, 既往歴の調查と腎機能検査は慎重を要する. 難聴の前兆としての耳鳴りも重要で, 最初 $1 \sim 2$ 回の使用後の反応に注意を要する。また，定期的 な聴力検査も必要である. 難聴が出たら速やかに 使用を中止する．特に結核性髄膜炎などのさいの $\mathrm{SM}, \mathrm{KM}$ の髄腔内注入は, 筋注より早く高度の 難聴がくるので注意を要する11.

2) Neuropathy

a) Isoniazid (INH)

元来, わが国では, INH の代謝型で外国に比 し, Slow inactivator が少く, Ripid inactivator が多いため，INH-Neuropathy は少いとされてい

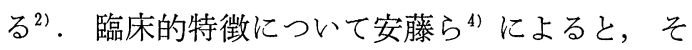
の頻度は $4.4 \%$ であるという。また，男性かつ高 年齢, 低体重者, 重症肺結核患者に発症し易い ${ }^{3)}$. 四肢末端から始まる左右対称性の Glove \& Stocking 型の Sensory Polyneuropathy が主体をな している。下肢の表在知覚障害レベルは70\%が膝 までで，運動神経を障害するものは僅かである． 知覚障害は表在，深部ともに障害されるが，前者 が先に侵され高度の深部知覚障害は比較的少い。

脊髄後索障害を推定させるものもあるが，錐体路 その他の脊髄障害の徵候は認められない. 少数で あるが軽い筋力低下を伴つて Mixed Polyneuropathy の像を呈するものがある. 病理学的所見 では, Cavanagh $は^{5)}$ rat に大量の INH を投与 した結果，病変が末梢神経に限局され，末期に脊 髄は後索にのみ病変が波及しているものもあつた としている。また，Zbinden は ${ }^{6)}$ ，病理解剖所見 で末梢神経の Waller 変性のみで脊髄には変化は 見られぬとしている。いずれにしろ，INH-Neuropathy では, 臨床的にも錐体路障害が認められ ぬのが原則であり，重症例では下肢の失調を伴つ た例もあることから，脊髄後索への病変の波及も 推定されている.

b) Ethambutol (EB)

安藤ら ${ }^{4)}$ は，発症はかなり急性で，90\%は 4 カ 月以内の短期間である。足のしびれに始り, 知覚
障害は上行し，膝ないし腰髄 Iのレベルに達す る。上肢の知覚障害は約 $30 \%$ の頻度である。下肢 の疼痛は少いが，下肢の振動知覚障害や失調およ び筋力低下がやや強く, これらの点は INH-Neuropathy と異つている．また，下肢の深部反射艺 進とくに膝蓋腱反射が半数例に認められる。これ らのことから，EB のそれは単なる Neuropathy ではなく Myelo-Neuropathy であることを示めし ている，つぎに，視力障害が程度の差はあれ，殆 どの症例に認められる特異性がある。半数例では 視力が 0.1 以下に低下するといわれている。なお， 馬場ら ${ }^{9)}$ は，視力障害は可逆的であるとしながら も，失明した症例を報告している。以上のことか ら，完成された臨床像は Myelo-Optico-Neuropathp であり，現在わが国で問題にされている SMON と極めて類似している. しかし，軽症例 や病像の完成前のものは Optico-Polyneuropathy または Polyneuropathy の像を呈する.

病理組織学的には，神経線維の脱髄を主体とす る所見を呈するとされている. Schmidt ら7) は， 猿に $\mathrm{EB}$ を大量投与し, その剖検結果を発表して いる。すなわち，視束交叉，視神経，延髄下部の 網膜体に早期に病変がみられ，ついで，赤核，延 髄運動神経核，延髄錐体，頸髄側索，脊髄前角な ぞに広範な領域の神経線維に脱䯣病変が 及んでい たとしている.馬場ら ${ }^{8)}$ は，EB は神経組織に強 、親和性を有するが，これは， $\mathrm{EB}$ 自体ではなく， その代謝産物に強い親和性があると述べている。 また, $\mathrm{EB}$ は赤血球に積極的に取り込まれ，臟器的 な取り込みでは，時間の経過と共に脳および眼球 への蓄積が認められ，視神経障害に関係があると している.

c) その他

Ethionamide (TH) は, INH とともに isonicotinic acid の誘導体であるので, Neuropathy を生ずる可能性を持つていると考えられる。しか し，THによる Neuropathy は軽症であること， また，THを単独使用されることが少く，そのた め判定するのに困難な場合が多い，著者は ${ }^{10)}, \mathrm{TH}$ 単独使用の 24 例について調查したが，眼がちかち 
かするとか複視などの眼症状. 手指振戦, 四肢末 端のしびれ感などを認めたが，共に軽症の域を脱 しない.

Cycloserine (CS) は，筋硬直おるび攣縮，手指 振戦，舌のもつれ，四肢末端のしびれ感などを著 者は認めている11)。しかし，その頻度は小であ り，かつ軽症のものであつた，その他，歩行失 調, 深部知覚障害, 下肢の麻疩なども副作用とし て稀にあるとされている。

\section{3）精神障害}

抗結核剂による精神障害は，一口でいえば症候 性精神障害である。その症状は，原因となつた抗 結核剤により若干のニューアンスを 異にする程度 のものである，軽度のものは，不眠，不定愁訴， 不安や恐怖心，焦躁感，感情変調など神経衰弱様 症候群ないし精神神経症様症状がある。病像の悪 化したものは，意識混濁，錯乱，幻覚や妄想体 験, 衝動行為, 街奇行為, 激しい躁うつ的気分变 勁などが認められる。この他，てんかん様㾠攣発 作も稀にみられる．以上の症状群は可逆的で，概 して該当薬品の投与中止により約 1 力月以内に消 退する。抗結核剤中，精神障害を発症する代表的 なものは, Cycloserine である. その他, Ethionamide, Ethambutol, Isoniazid などを挙げられ るが，発症頻度は Cycloserine に比しはるかに少 い.

a) Cycloserin (CS)

CS 精神障害の発現率は，報告者により差があ るが，これは，精神障害を判定する方法や基準に 起因すると考える，Epistein ら ${ }^{12)} は 36.8 \%$, Lewis ら ${ }^{13)}$ は50\%，徳臣ら ${ }^{3)}$ は $28.5 \%$ と述べている．著 者の調查では ${ }^{11)}$, 軽症のものまで含めると $58.5 \%$, 精神科的専門医の治療を必要とするものは $6.5 \%$

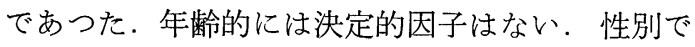
は女性に好発する傾向がある。つぎに，精神障害 の既往歴中, 特に精神分裂病は既存症状を増悪し たり，誘発する危険性があるので CS の使用にさ いして十分考慮する必要がある. Rankier ${ }^{13)}$, Vall. ade $ら^{15)}$, 志田 ${ }^{16)}$ は環境因子を重要視している. 著者も心的葛藤要因が発症に重要な役割をなして
いると考える，発症までの期間は，早いもので 2 〜 3 日目頃であるが，多くは 1 週間前後である． いわゆる強度の精神障害は，2〜4力月以内に $57.2 \%$ が突発的に出現する。てんかん様痓綝発作 は，1〜3 カ月以内に発症し，それ以降の長期服 用者では稀である。病像については 6 型に分類で きる、急性錯乱型 (34.3\%), 精神分裂病 (20\%), 躁うつ型，てんかん型，神経衰弱型，神経症型で ある.経過および転帰は，精神分裂病以外は，CS の投与を中止するのみで $69.7 \%$ が 1 力月以内に後 遺症を残さず治癒している，脳波検查では，11例 中 $45.6 \%$ に異常所見が認められ，とくに2 3 カ 月目の記録が著明である。なお， CS の痤攣誘起 機序については，諸説があるが現在のところ不明 である．臓器別に CS の取り込みをみると表 1 の 通りである。これは，血液濃度とは逆に脳内に市 いて，徐々に CS と強く結合する機構の存在する 可能性が考えられる.

表 1 CS の体内臟器蓄秒垂

\begin{tabular}{c|c|c}
\hline & 注射30分後 & 注射 2 時間後 \\
\hline 脳 & $14.5(\gamma / \mathrm{g})$ & $25.8(\gamma / \mathrm{g})$ \\
肝 & $28.8(\prime \prime)$ & $11.7(\prime \prime)$ \\
腗 & $24.7(\prime \prime)$ & $53.5(\prime \prime)$ \\
肾 & $86.5(\prime \prime)$ & $8.9(\prime \prime)$
\end{tabular}

b) Ethionameide (TH)

$\mathrm{TH}$ 精神障害の発症率については報告がなく不 明である．著者の経験 ${ }^{10)}$ では恐らく低率であると 推定する．発症は，CS が突発的であつたのに反 し, 平均 4.2 力月目に不眠, 頭痛, 不定愁訴，不 安, 焦躁, 抑うつ気分, しびれ感, 手指振戦など が75\%に前駆症状として出現する。これらの症状 群に対し，何等の処置も加えられなかつた場合, 数カ月の経過を経て感情不安定, 夜間せん妄, 妄 想体験, 不安, 焦躁, 不眠, 彿徊, 幻聴, 自我障 害，異常体感などを有する錯乱状態に陌る，意識 障害は軽度ないし中等度のものであるが $80 \%$ に認 められる。転帰は $\mathrm{TH}$ 投与を中止することで， 精神症状は完全に消失する. 以上の他，TH 投与 によるペラグラの発症に伴い，二次的なペラグラ 
精神障害を著者は経験している。

c) Ethambutol (EB)

昨今， $\mathrm{EB}$ による精神障害の 報告が 散見され

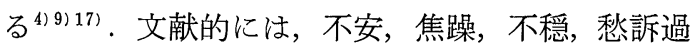

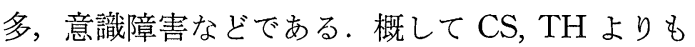
軽症と思われる。

d) Isoniazid (INH)

INH が使用され始めた当初, 精神障害について 多くの報告がなされた。しかし，近年は臨床的に INH 精神障害を殆ど経験しない.

4) 治療

抗結核剤に起因する副作用の治療は，その原因 となる薬剤を中止することが原則的に必要であ る.

聴覚障害に対しては，各種のVitamin 製剤の 大量投与，脳血液循環促進剤などを使用している が，現在決定的な有効治療法はない. 初期症状で ある耳鳴や，軽度の難聴の段階で投与を中止する ことが最大の予防である。

$\mathrm{INH}$ は Vitamin $\mathrm{B}_{6}$ 代謝拮抗剤として生体の Vitamin $\mathrm{B}_{6}$ 代謝を阻害し，Vitamin $\mathrm{B}_{6}$ 欠乏をき たす.これが Neuropathy 発生の一因とされてい るため, Vitamin $\mathrm{B}_{6}$ が予防に治療に有効とされ ている.この他にも，Vitamin $\mathrm{B}_{2}$ ，ニコチン酸ア ミド, Vitamin $\mathrm{B}_{1}, \mathrm{~B}_{2}$ 複合体やパントテン酸が良 いとするものもある. 著者は ${ }^{18)}$ ，補酵素型 Vita$\min \mathrm{B}_{12}$ を使用し，かなりの効果を得た経験があ る.

EB-Neuropathy は，現在適格な治療法はなく， 投与を中止することが決定的に重要である.
精神障害でも投与を中止するのが 原則である. しかし，軽症の場合は，抗結核剤を継続投与しつ つ Minor Tranquilizer を使用し, 症状が改善さ れることがしばしばである、急性錯乱状態や幻覚 妄想体験を有する場合は，投与を中止することが 必要である. 症状に応じて Minor あるいは Major Tranquilizer を使用すべきである。なお，衝動的 に自殺を企図することがあるので，不慮の事故に 対し常に注意することが大切である.

\section{文 献}

1）美甘ほか：医療原性疾患, 南江堂, 1969, 10.

2) 砂原 : 結核，39，278(1964).

3）徳臣ほか：日本胸部臨床，23，445(1964).

4) 安藤ほか : 綜合臨床, 18-10, 2048(1969).

5) Cavanach, B. : J. Neurol. Neurosurg., Psychiat. 30, 26(1967).

6) Zbinden, G. et al. : Schweiz. Z. Path., 18, 1198(1955).

7) Schmidt, H. : Ann. N. Y. Acad. Sci., 135, $732(1966)$.

8）原ほか: 結核，45-4, 129(1970).

9）馬場ほか: 結核，42-1，1(1967).

10）梅根: 65回日本精神神経学会報告, 長崎 (1968).

11）梅根ほか：埼玉医学会誌，4-1，18(1969).

12) Epistein, L. et al.: A Preliminary Report, Antibiot., Med. 1, 80 (1955).

13) Lewis, W. et al.: Dis. Chest., 32-2, 172 (1957).

14) Rankier, G. : Canad. Med. Ass. J., 93-1, 35 (1965).

15) Vallade, L. et al. : Presse Méd., 67-4, 138 (1959).

16）志田：三浦岱栄教授還暦記念論文集, 259(1963).

17）山崎ほか : 新潟医学会誌, 82-12, 785(1968).

18）梅根ほか : 埼玉医学会報告, 浦和，1971，3. 